\title{
Teachers' Beliefs: Positive or Negative Indicators of Inquiry-Based Science Teaching?
}

\author{
Salifu Maigari Mohammed ${ }^{1, *}$ \\ ${ }^{1}$ Department of Teacher Education, School of Education and Leadership, College of Education, University of Ghana, \\ Legon-Accra, Ghana \\ *Correspondence: Department of Teacher Education, School of Education and Leadership, College of Education, \\ University of Ghana, Legon-Accra, P. O. Box LG 1181, Ghana. Tel: 233-242-984-946. E-mail: \\ smmohammed@ug.edu.gh
}

Received: January 3, $2022 \quad$ Accepted: January 25, 2022 Online Published: February 10, 2022

doi:10.5430/wje.v12n1p17 URL: https://doi.org/10.5430/wje.v12n1p17

\begin{abstract}
Inquiry-based science teaching is an innovative pedagogy that is more effective than traditional instruction in promoting scientific literacy. However, teachers must develop strong favourable beliefs about inquiry teaching before they can successfully employ it to improve students' learning outcomes. Despite its importance few studies have been done to examine teachers' beliefs about inquiry teaching in places, like Africa, where there are serious inquiry curricula implementation challenges. This study investigated whether teachers' beliefs are positive or negative indicators of inquiry-based science teaching. Convergent parallel mixed methods was used for the study. Purposive and stratified random sampling were used to select 308 and subsample of 18 integrated science teachers from public and private junior high schools (JHSs) from urban and rural areas. Administration of questionnaires and semi-structured interviews were used for the quantitative and qualitative data collection. The questionnaire has content and construct validities and is reliable. The interview schedule is credible and dependable. One finding suggests that most teachers in the research setting hold weak beliefs about inquiry teaching but strong beliefs about traditional instruction, that are negative indicators of inquiry-based science teaching. Other findings indicate that there are significant school type and academic qualification differences in teachers' beliefs about inquiry-based science teaching. One implication of the findings is that currently most teachers in the study context do not hold strong positive beliefs necessary for the implementation of inquiry-based science curricula. It is recommended that regular inquiry-based in-service trainings be designed to improve teachers' beliefs. It is also recommended that inquiry-based in-service trainings should be designed based on teachers' school type and academic qualifications.
\end{abstract}

Keywords: beliefs, inquiry-based teaching, integrated science, junior high school, traditional instruction

\section{Introduction}

Content and pedagogical content knowledge are essential for teacher-centred science instruction. However, one critical factor "that influences teachers' intentions and abilities to employ innovative pedagogy, including inquiry teaching, is the teachers' complex belief systems about teaching and views of science" (Crawford, 2007, p. 636). The inquiry-based approach is effective in improving various students' learning outcomes (Furtak, Seidel, Iverson, \& Briggs, 2012). As a result, changes in science curricula have been done to strengthen and enhance inquiry pedagogy in places, like USA, where there are significant successes in inquiry curricula implementations (Marec, Tessier, Langlois, \& Potvin, 2021; National Research Council [NRC], 2012; Silm, Tiitsaar, Pedaste, Zacharia, \& Papaevripidou, 2017). Likewise, reforms in science curricula aimed at adopting and implementing inquiry pedagogy have been done in many other places (Chabalengula \& Mumba, 2012; Curriculum Research and Development Division [CRDD], 2012; Ssempala, 2017). In the inquiry-based approach, students engage in relevant, meaningful, interesting, hands-on, and minds-on real-life investigations into science phenomena. The teacher's role is to guide, facilitate, couch, and mentor students to ask scientific questions; formulate hypotheses; design and conduct investigations; and collect and analyse data. Again, the teacher facilitates students to construct explanations from data, engage in collaborative discourse; and communicate their ideas and results with peers and others (Furtak et al., 
2012; NRC, 2012).

However, there is rare and poor implementation of science inquiry teaching in many classrooms (Mohammed, Amponsah, Ampadu, \& Kumassah, 2020; Mugabo, 2012; Ssempala, 2017). The influence of various contextual and demographic factors have been examined across the globe in efforts to explain and predict teachers' adoption and frequency of inquiry teaching (Ramnarain, 2016; Ramnarain \& Hlatswayo, 2018; Tang, Qiu, Meng, Li, \& Zhang, 2020). Some of the factors have been found to hinder inquiry teaching in certain contexts but, the same factors have been found to have no significant influence in other contexts. There must be complex interactions of multiple factors giving rise to various implementations of inquiry teaching in various contexts. Nevertheless, researchers agree that examination of teachers' beliefs is important in understanding their instructional decisions and practices (Nespor, 1987; Pajares, 1992). There have been sufficient studies into the influence of teachers' beliefs on inquiry-based science curricula implementation in places, like USA, where there are significant implementation successes (Correia \& Harrison, 2020; Kind, 2016; Min, Akerson, \& Aydeniz, 2020; Veal, Riley Lloyd, Howell, \& Peters, 2016). Contrary, the influence of teachers' beliefs on inquiry-based science curricula implementation has not been exhaustively explored in places, like Africa, where there are serious implementation challenges. The fact that "many teachers have been left to create their own images of inquiry teaching" (Anderson, 2002, p. 3) and, given that contextual and demographic characteristics influence translation of teachers' beliefs into classroom practices (Crawford, 2007), suggest that additional research are required to understand the influence of teachers' existing beliefs on their instructional decisions and practices in various contexts.

\subsection{Purpose of the Study}

This study examined whether teachers' beliefs are positive or negative indicators of inquiry-based science teaching. Again, the study examined whether there are school type (public and private) and/or academic qualification (certificate, graduate, and post graduate) differences in teachers' beliefs and, whether differences in beliefs indicate positive or negative differences in inquiry-based science teaching.

\subsection{Research Questions}

Research questions used to guide the study are:

1. Are teachers' beliefs positive or negative indicators of inquiry-based science teaching?

2. Are there school type (public and private) differences in teachers' beliefs? and, do the differences indicate positive or negative differences in inquiry-based science teaching?

3. Are there academic qualification (certificate, graduate, and post graduate) differences in teachers' beliefs? and, do the differences indicate positive or negative differences in inquiry-based science teaching?

\section{Conceptual Framework}

\subsection{Beliefs about Science Teaching}

Individuals' beliefs about science teaching are psychological understandings, premises, or propositions about science teaching that have sufficient validity to guide their thoughts and behaviours (Pajares, 1992; Tondeur, van Braak, Ertmer, \& Ottenbreit-Leftwich, 2016). The fact that two teachers with similar knowledge about science may teach in different ways suggest that understanding teachers' beliefs is important to understand and predict their instructional decisions. Individuals' beliefs about science teaching are relatively stable and resistant to change, have strong affective and evaluative components, are deeply personal, do not require universal or group consensus to validate and determine their relevance, and exist in the individuals' episodic memories (Bryan, 2012; Nespor, 1987; Pajares, 1992). Individuals hold a continuum of beliefs about science teaching with some being core and others being peripheral (Bryan, 2012; Pajares, 1992).

Individuals hold several components of beliefs about science teaching in their belief systems. These include beliefs about "characteristics of science teachers and the learning environment", "how students learn science", "nature of science curriculum", and "science lesson design and implementation" (Karaman \& Karaman, 2013; Sampson, Enderle, \& Grooms, 2013). Teachers' beliefs can broadly be categorised as traditional (behaviourist) or constructivist (inquiry) in nature (Tondeur et al., 2016). Teachers with traditional beliefs about science teaching consider science curriculum as a list of facts that must be presented to students through rigid teaching approaches. They engage in traditional classroom interactions in which teachers ask series of close-ended questions for students to answer. They engage in summative assessment of learning to determine whether transmission of scientific knowledge was successful or not. Teachers with traditional beliefs employ lecture and "chalk-and-talk" methods to impart 
knowledge to students (Karaman \& Karaman, 2013; Mansour, 2013; Sampson et al., 2013; Tondeur et al., 2016).

In contrast, teachers with constructivist (inquiry-based) beliefs about science teaching value active participation of students in constructing their own knowledge. They consider science learning as practices where students gradually expand their networks of ideas through interaction with their peers and materials in the environment (Karaman \& Karaman, 2013; Mansour, 2013; Sampson et al., 2013; Tondeur et al., 2016). They consider science learning as inquiry into students' generated questions and, a process that can proceed in various directions away from the original plans (Kazempour, 2014). Teachers with inquiry-based beliefs provide opportunities and support for students to reflect as the students develop conceptual understandings and learn more about scientific inquiry (Crawford, 2007; Mansour, 2013).

\subsection{Effects of Beliefs about Science Teaching}

Teachers' beliefs about science teaching are the best indicators of their instructional thinking, decisions, and behaviours (Pajares, 1992). Teachers' beliefs strongly influence how they conceptualize tasks and learn from classroom practices (Nespor, 1987). Teachers' beliefs about science teaching allow them to minimise dissonance and confusion in their instructional practices (Pajares, 1992). Beliefs about science teaching enable teachers to identify colleagues who share similar beliefs. This allows them to form groups and social systems for collaborative reflections, discussions, and support. Teachers rely on their beliefs about science teaching to continually evaluate and judge the effectiveness and appropriateness of their students' learning, teaching strategies, and the learning environment. Teachers rely on their core episodic beliefs to handle difficult and complex problems/tasks when they are uncertain of the information and skills needed and, when it is not workable to employ cognitive and information processing strategies (Pajares, 1992). Teachers' beliefs about science teaching enable them to identify aspects of instructional strategies to adapt in their own classroom behaviours (Eisenhart, Shrum, Harding, \& Cuthbert, 1988). Teachers' strongly held beliefs serve as powerful filters through which they filter innovative approaches for teaching and learning science. Individuals who share similar beliefs about science teaching are likely to interpret instructional problems/tasks in certain ways and prefer certain courses of action over others (Eisenhart et al., 1988).

\subsection{Contextual and Demographic Influences on Beliefs about Science Teaching}

The formation, development, and translation of teachers' beliefs into classroom practice are influenced by contextual and demographic characteristics. Studies show that contextual and demographic characteristics that influence teachers' beliefs about science teaching include economic status and educational development of a place (Tang et al., 2020), resources, time constraint, school culture (Ramnarain, 2016), laboratory facilities, class size, curriculum content, nature of examinations, teacher accountability (Ramnarain \& Hlatswayo, 2018), students' confidence and abilities, availability of technology (Ogegbo, 2021), subject-matter specialization, administrative support, financial support, language of instruction (Baroudi \& Rodjan Helder, 2021), teaching experience (Isiksal-Bostan, Sahin, \& Ertepinar, 2015), gender (Karaman \& Karaman, 2013) and others.

\subsection{Formation of Beliefs about Science Teaching}

Most researchers agree that formation and development of teachers' beliefs about science teaching occur throughout their lifetime, especially from science instructional experiences they had as students in elementary and high schools (Lasley, 1980; Nespor, 1987; Pajares, 1992). The richly, detailed, episodic memory of science instruction that individuals have from some influential teaching practices in the past strongly influenced the formation of their beliefs about science teaching and, serve as inspiration and templates that determine their own science teaching practices. Teachers who passed through elementary and high school education systems that were based on traditional foundations of education (Karaman \& Karaman, 2013) and, who had science learning experiences that involved teacher-centred and occasional confirmatory laboratory activities (Kazempour, 2014) formed and developed traditional beliefs about science teaching. These prior beliefs are then reinforced and shaped by pre-service and in-service teacher education that places heavy emphasis on science content at the expense of reflections about the processes and philosophy of science (Saad \& BouJaoude, 2012). In contrast, teachers who passed through elementary and high school education systems that were based on constructivist foundations of education and, who had science learning experiences that were student-centered formed and developed beliefs about constructivist (inquiry-based) science teaching.

\subsection{Preservice and In-Service Science Education}

Teacher-centered science education emphasizes the acquisition of content and pedagogical content knowledge. Not much emphasis is placed on the development of prospective and in-service teachers' beliefs. However, researchers agree that it is important for science education to develop teachers with strong positive beliefs (Buldur, 2017; Tatar, 
2015; Veal et al., 2016). Some beliefs that individuals bring into preservice education institutions are consistent with the desired aims and goals of science teacher education but, many other beliefs are inconsistent with the aims and goals of teacher education. Similarly, most individuals enter classrooms with the view that teaching involves transmission of knowledge for students to receive (Pajares, 1992). One way to influence teachers to develop positive beliefs about innovative science teaching is to engage them and direct their thinking toward positive aspects of science teaching (Ajzen, 2001). This can take the form of methods courses, interventions, professional developments, mentorships, etc. In the process preservice and in-service teachers are confronted with adequate objective and valid data that reflectively and self-consciously make them aware of their existing beliefs. After which new and alternative practices are presented to change the teachers' beliefs and practices (Nespor, 1987). Generally, teachers' epistemological and pedagogical beliefs are relatively stable and, long-term professional developments, interventions, and methods courses are required to change teachers' beliefs and instructional practices (Tondeur et al., 2016).

\section{Methods}

\subsection{Research Design}

This study employed convergent parallel mixed methods for the collection of quantitative and qualitative data (Creswell, 2009; Creswell \& Plano Clark, 2007). The quantitative aspect involved survey of the main sample of teachers. The qualitative aspect comprised multiple-case studies of subsample of the participants. Equal priority was given to both data types. I integrated the quantitative and qualitative data in the presentation and discussion of the results. The survey permitted large standardised data to be collected to ascertain extent of the issues investigated. It also allowed for the use of statistical tools and generalization of the findings (Ornstein, 2006; Wolf \& Fraser, 2008). The qualitative data permitted empirical corroboration and interpretation of the quantitative results. It also facilitated in-depth understanding and unravelled multiple perspectives of the issues studied. The multiple case studies allowed issues that were not initially considered to emerge.

\subsection{Sample}

A main sample of 308 and subsample of 18 integrated science teachers from public and private JHSs from urban and rural areas of the Central Region of Ghana were selected using purposive and stratified random sampling a in multi-stage procedure. Two hundred and seventy-seven (89.94\%) were male teachers and 31(10.07\%) were female teachers. One hundred and seventy-six (57.1\%) were public JHS teachers and $132(42.9 \%)$ were private JHS teachers. Two hundred (64.94\%) were certificate teachers, 105(34.09\%) were graduate teachers and, 3(0.97\%) were post graduate teachers. The certificate teachers comprised holders of Diploma in Basic Education (DBE), Teachers' Certificate "A", SSCE, WASSCE, and the like. The graduate teachers comprised holders of BED, BSC, and BA certificates. The post graduate teachers comprised holders of MED, MSC, and MA certificates. One hundred and seventy-eight $(58.36 \%)$ teachers had 1-5 years teaching experience, 79 (25.65\%) had 6-10 years, 44(14.29\%) had 11-15 years, and $7(2.27 \%)$ had over 15 years of teaching experiences respectively. One hundred and sixty-three $(52.92 \%)$ were urban school teachers and $145(47.08 \%)$ were rural school teachers.

\subsection{Instruments}

\subsubsection{Teachers' Questionnaire}

I constructed a questionnaire to measure teachers' beliefs about inquiry-based science teaching. The questionnaire was modelled on past beliefs instruments (Karaman \& Karaman, 2013; Sampson et al., 2013). Four components of beliefs were identified from the literature. They are beliefs about "science lesson design and implementation", "characteristics of science teachers and the learning environment", "how students learn science", and "nature of science curriculum".

Initially, I constructed 48 items to cover the four components. Construction of the items was based on 5-point Likert scale, from strongly disagree $=1$, disagree $=2$, uncertain $=3$, agree $=4$, to strongly agree $=5$. The scale is a continuum from traditional to inquiry teaching beliefs. 1 and 2 represent traditional teaching beliefs and 4 and 5 represent inquiry teaching beliefs. Content validity of the instrument was determined using extensive literature and expert judgments of two science education professors. The experts recommended 20items for pilot testing. Twenty-eight items were removed for being similar and measuring the same things as other items. I pilot tested three equivalent forms of the questionnaire using 39 and 52 science teachers respectively from two different municipalities in one region and, 108 science teachers from another municipality in another region of the country. Samples for the pilot test did not participate in the main data collection. After preliminary item analysis the first parallel form, with the highest overall reliability $(\alpha=.71)$, was adopted for the main data collection. 
Following the main data collection, confirmatory Principal Component Analysis (PCA) with varimax rotation was conducted to determine construct validity of the questionnaire. The data was suitable for PCA [KMO (.82); Bartlett's sphericity test $\left.\chi^{2}[(171)=1657, p<.001]\right]$. Seven items were removed for loading onto multiple components. Thirteen items yielded four interpretable components that explained $66.45 \%$ of the total variance. This is consistent with variances in similar studies (Karaman \& Karaman, 2013; Sampson et al., 2013). Final reliability estimates of the components (characteristics of science teachers and the learning environment, $\alpha=.74$; nature of science curriculum, $\alpha=.82$; how students learn science, $\alpha=.77$; science lesson design and implementation, $\alpha=.74$ ) and entire instrument, $\alpha=.66$ are satisfactory for educational research.

\subsubsection{Interview Schedule}

I designed a semi-structured interview schedule for the qualitative data collection. The schedule contains open-ended items that were used to elicit four components of participants' beliefs about science teaching (characteristics of science teachers and the learning environment, nature of science curriculum, how students learn science, and science lesson design and implementation). The open-ended nature of the items allowed participants to give detailed information. It also allowed the interviewer to probe, prompt, and follow up participants' responses for further explanations. The flexibility of the semi-structured schedule allowed the interviewer to explore relevant issues that emerged during the interviews (Jacob \& Furgerson, 2012). It also allowed the interviewer to change the order of the questions according to responses from the participants.

\subsection{Data Collection Procedure}

The quantitative data collection comprised physical (paper-based) administration of questionnaires to the main sample of teachers which yielded $87.5 \%$ return rate (308 out of 352 administered questionnaires). The qualitative data collection, following the survey, entailed face-to-face interviews with a subsample of 18 teachers in public and private schools in urban and rural areas. I made suitable arrangements with each teacher to conduct the interviews. The interviews were audio recorded. All the respondents gave their consents for the interviews. The signed consent documents contained explanations of ethical issues about research involving human participants. There was adequate rapport between me and the interviewees. This permitted the participants to open up and talked freely. Most of the interviews were 45 minutes long.

\subsection{Data Analysis}

I conducted preliminary inspection of the quantitative data for removal of outliers and cases with missing values. I reverse coded negative worded items. I checked the quantitative data to ensure that assumptions for parametric analysis were satisfied. The audio recorded interviews were transcribed and the transcripts were audited and edited. I computed descriptive statistics from the quantitative data and integrated the results with qualitative themes and sample quotations to answer research question one.

I computed One-way Multivariate Analysis of Variance (MANOVA) with school type (public and private) and academic qualification (certificate, graduate, and post graduate) as independent variables to answer research questions two and three respectively. The dependent variables are components of beliefs (nature of science curriculum, how students learn science, science lesson design and implementation, and characteristics of science teachers and the learning environment). Means and standard deviations of items constituting the components of beliefs were also calculated. Results from the inferential statistics were triangulated with qualitative themes and sample quotations.

\section{Results}

\subsection{Are Teachers' Beliefs Positive or Negative Indicators of Inquiry-Based Science Teaching?}

Table 1 indicates that, generally, the teachers held modest beliefs about inquiry-based science teaching $(\mathrm{M}=3.27$, $\mathrm{SD}=.35)$. While they held strong inquiry-based beliefs about the "nature of science curriculum" $(\mathrm{M}=4.32, \mathrm{SD}$ $=.59)$, "science lesson design and implementation" $(\mathrm{M}=4.17, \mathrm{SD}=.61)$, and "how students learn science" $(\mathrm{M}=$ $4.10, \mathrm{SD}=.65)$, they held weak inquiry-based but strong traditional beliefs about "characteristics of science teachers and the learning environment" $(\mathrm{M}=1.20, \mathrm{SD}=.76)$. 
Table 1. Descriptive Statistics of Teachers' Beliefs about the Nature of Science Curriculum, Characteristics of Science Teachers and the Learning Environment, Science Lesson Design and Implementation, and How Students Learn Science

\begin{tabular}{|c|c|c|c|c|c|c|c|}
\hline \multirow[b]{3}{*}{ Component of belief } & \multicolumn{7}{|c|}{ Responses } \\
\hline & SD & $\mathrm{D}$ & $\mathrm{U}$ & A & SA & \multirow{2}{*}{$\begin{array}{l}\text { Average } \\
\text { item mean }\end{array}$} & \multirow{2}{*}{$\begin{array}{l}\text { Average } \\
\text { item } \\
\text { standard } \\
\text { deviation }\end{array}$} \\
\hline & $\mathrm{n}(\%)$ & $\mathrm{n}(\%)$ & $\mathrm{n}(\%)$ & $\mathrm{n}(\%)$ & $\mathrm{n}(\%)$ & & \\
\hline Nature of science curriculum & & & & & & 4.32 & .59 \\
\hline $\begin{array}{l}\text { Science teachers should write science } \\
\text { concepts on the board for students for JHS } \\
\text { students to copy }\end{array}$ & $14(4.5)$ & $60(19.5)$ & $21(6.8)$ & $141(45.8)$ & $72(23.4)$ & & \\
\hline $\begin{array}{l}\text { Science curricula should encourage JHS } \\
\text { students to learn to interpret data to } \\
\text { develop explanations. }\end{array}$ & $0(0.0)$ & $13(4.2)$ & $5(1.6)$ & $184(59.7)$ & $106(34.4)$ & & \\
\hline $\begin{array}{l}\text { JHS students need to be given } \\
\text { opportunities to work in groups }\end{array}$ & $0(0.0)$ & $8(2.6)$ & $3(1.0$ & $152(49.4)$ & $145(47.1)$ & & \\
\hline $\begin{array}{l}\text { Science curricula should help JHS students } \\
\text { develop skills of collecting and recording } \\
\text { data. }\end{array}$ & $0 .(0.0)$ & 13.(4.2) & $12(3.9)$ & $153(49.7)$ & $130(42.2)$ & & \\
\hline Science lesson design and implementation & & & & & & 4.17 & .61 \\
\hline $\begin{array}{l}\text { To prepare students for future classes, } \\
\text { science curricula should encourage JHS } \\
\text { students to challenge scientific ideas. }\end{array}$ & $0(0.0)$ & $19(6.2)$ & $25(8.1)$ & $156(50.6)$ & $108(35.1)$ & & \\
\hline $\begin{array}{l}\text { During lessons, JHS students need to be } \\
\text { given opportunities to challenge scientific } \\
\text { ideas. }\end{array}$ & $0(0.0)$ & $13(4.2)$ & $20(6.5)$ & $177(57.5)$ & $98(31.8)$ & & \\
\hline $\begin{array}{l}\text { Teachers should allow JHS students to } \\
\text { reason and reach collective decisions } \\
\text { together to help determine the focus and } \\
\text { direction of science lessons. }\end{array}$ & $0(0.0)$ & $13(4.2)$ & $13(4.2)$ & $179(58.1)$ & $103(33.4)$ & & \\
\hline How students learn science & & & & & & 4.10 & .65 \\
\hline $\begin{array}{l}\text { Lessons should be designed to allow JHS } \\
\text { students learn systematically instead of } \\
\text { lectures. }\end{array}$ & $0(0.0)$ & $14(4.5)$ & $13(4.2)$ & $143(46.4)$ & $138(44.8)$ & & \\
\hline $\begin{array}{l}\text { JHS students learn science the most when } \\
\text { they interpret data to develop explanations } \\
\text { for science phenomena. }\end{array}$ & $0(0.0)$ & $20(6.5)$ & $37(12.0)$ & $186(60.4)$ & $65(21.1)$ & & \\
\hline $\begin{array}{l}\text { Science teachers should act as resource } \\
\text { persons to support JHS students examine } \\
\text { and evaluate the quality of data rather than } \\
\text { explaining how things work. }\end{array}$ & $0(0.0)$ & $28(9.1)$ & $21(6.8)$ & $171(55.5)$ & $88(28.6)$ & & \\
\hline Characteristics of science teachers and the & arning en & ronment & & & & 1.20 & .76 \\
\hline $\begin{array}{l}\text { A good science teacher is really good at } \\
\text { explaining and defining science concepts } \\
\text { for JHS students. }\end{array}$ & $0(0.0)$ & $51(16.6)$ & $18(5.8)$ & $121(39.3)$ & $118(38.3)$ & & \\
\hline $\begin{array}{l}\text { JHS students are more likely to understand } \\
\text { a concept if the teacher defines and } \\
\text { explains it clearly. }\end{array}$ & $0(0.0)$ & $31(10.1)$ & $8(8.2)$ & $117(38.0)$ & $152(49.4)$ & & \\
\hline $\begin{array}{l}\text { Science curricula needs to focus on } \\
\text { defining and explaining science concepts } \\
\text { that JHS students need to know. }\end{array}$ & $0(0.0)$ & $35(11.4)$ & 11(3.6) & $144(46.8)$ & $118(38.3)$ & & \\
\hline Beliefs about science teaching & & & & & & 3.27 & .35 \\
\hline
\end{tabular}

$\mathrm{SD}=$ Strongly Disagree, $\mathrm{D}=$ Disagree, $\mathrm{U}=$ Uncertain, $\mathrm{A}=$ Agree, $\mathrm{SA}=$ Strongly Agree

Note: High means represent inquiry beliefs, low means represents traditional beliefs 
Most of the teachers expressed strong inquiry-based beliefs about the "nature of science curriculum" and agreed that science curriculum should encourage students to develop skills of collecting and recording data 283(91.9\%), learn to interpret data to develop explanations for science phenomena 290(94.1\%), and give students opportunity to work in groups $297(96.5 \%)$ to construct their own knowledge. However, interview responses from a subsample show that many teachers held strong beliefs based on partial conceptions of inquiry while many others held strong beliefs based on traditional conceptions of science teaching (Table 2). The interview results suggest that the teachers' inquiry-based beliefs about the nature of science curriculum are not as strong as the quantitative results apparently show.

Table 2. Emergent Interview Themes on Teachers' Beliefs about the Nature of Science Curriculum, Science Lesson Design and Implementation, How Students Learn Science, and Characteristics of Science Teachers and the Learning Environment

\begin{tabular}{|c|c|c|}
\hline \multirow{2}{*}{ Component of beliefs } & \multicolumn{2}{|c|}{ Emergent interview themes on beliefs about science teaching } \\
\hline & Traditional beliefs & Partial inquiry-based beliefs \\
\hline Nature of science curriculum & $\begin{array}{l}\text { - Separation of practical and theory } \\
\text { aspect of science }\end{array}$ & $\begin{array}{ll}\text { - } & \text { De-emphasize wide content coverage } \\
\text { - } & \text { Focus on meaningful learning } \\
\text { - } & \text { Sufficient time for inquiry } \\
\text { - } & \text { Students' autonomy }\end{array}$ \\
\hline $\begin{array}{l}\text { Science lesson design and } \\
\text { implementation }\end{array}$ & $\begin{array}{l}\text { - } \quad \text { Separate time for theory and } \\
\text { practical lessons } \\
\text { - } \quad \text { Strict monitoring of students' } \\
\text { behaviours } \\
\text { - } \quad \text { Students' inabilities, age, } \\
\text { - } \quad \text { Giving step-by-step procedures }\end{array}$ & $\begin{array}{ll}\text { - } & \text { Active students' involvement } \\
\text { - } & \text { Elicit students' prior experiences }\end{array}$ \\
\hline How students learn science & $\begin{array}{l}\text { - } \quad \text { Give step-by-step procedures } \\
\text { - } \quad \text { Should be guided by teacher }\end{array}$ & $\begin{array}{l}\text { - Provision of support and favourable } \\
\text { conditions for inquiry } \\
\text { - Students take responsibility for their } \\
\text { learning }\end{array}$ \\
\hline $\begin{array}{l}\text { Characteristics of science teachers } \\
\text { and the learning environment }\end{array}$ & $\begin{array}{l}\text { - } \quad \text { Creating conducive and quiet } \\
\text { classroom environment } \\
\text { - } \quad \text { Controlling students' behaviour } \\
\text { - } \quad \text { Dealing with large class sizes and } \\
\text { seating arrangements } \\
\text { - } \quad \text { Teacher try hands-on activities }\end{array}$ & \\
\hline
\end{tabular}
$\mathrm{N}=18$

Interviewees who expressed strong beliefs based on partial conceptions of inquiry believe that science curricula should de-emphasize wide content coverage and focus on meaningful learning and engagement of students in science investigations (Table 2). They believe that some topics in the current JHS syllabus should be taken away or merged with others.

The ... JHS syllabus is loaded. It makes science learning "chew and pour" (rote memorization and recall) without understanding ... Some topics should be taken away from the syllabus. It is better for students to learn to understand the little content that is available. (ST 12)

However, interviewees who expressed strong beliefs based on traditional conceptions of teaching believe that science curricula should consist of separate theory and practical aspects (Table 2), where separate periods are allocated for science theory (concepts and principles) learning and, hands-on activities to verify the concepts learned.

The curriculum should be prepared in such a way that time allocated for experiments (hands-on activities) will be much longer than time allocated for theory (concepts) learning. (ST 6) 
Again, Table 1 indicates that most of the teachers held strong inquiry-based beliefs about "science lesson design and implementation" and agreed that JHS students should be given opportunities to challenge scientific ideas through argumentations, discussions, and presentations 275(89.5\%), and allowed to reason to reach collective decisions in order to help determine the focus and direction of science lessons $282(91.5 \%)$.

However, interview responses from a subsample suggest that the teachers' inquiry-based beliefs about "science lesson design and implementation" are not strong as the quantitative results appear to show. Many interviewees held strong beliefs based on partial conceptions of inquiry while most interviewees held strong beliefs based on traditional conceptions of science teaching. Participants who espoused strong beliefs based on traditional conceptions believe that there should be separation in designing and implementing theory (concepts) and practical (hands-on) lessons in classrooms (Table 2).

They also believe that teachers should strictly monitor the behaviour and actions of students during hands-on activities by giving students step-by-step procedures and safety precautions to follow. Again, they believe that science teachers should plan lessons ahead, gather all chemicals and materials needed, and try out the experiments before going to classrooms.

The teacher should set up the equipment ... and give students the steps involved in doing the experiment (hands-on activities) (ST 15)

If there are chemicals involved ... the teacher should prepare ahead. The teacher can also perform the experiment ahead to find out if the materials are working. (ST 16)

Table 1 also indicates that most of the teachers held strong inquiry-based beliefs about "how students learn science" and agreed that JHS students learn science the most when teachers act as resource persons 259(84.1\%) and support the students to examine and evaluate the quality of data rather than explaining how things work. Again, most of the teachers agreed that science lessons should be designed to allow students learn new concepts systematically like scientists instead of through lectures, reading, and demonstrations 281(91.2\%). However, interview responses from a subsample suggest that the teachers' inquiry-based beliefs about "how students learn science" are not as strong as the quantitative results apparently show. Many teachers held strong beliefs based on partial conceptions of inquiry while many others held strong beliefs based on traditional conceptions of science teaching. Respondents who expressed strong beliefs based on partial conceptions of inquiry believe that students should be given support and favourable conditions to engage in science learning (Table 2). They also believe that students engaged in inquiry appreciate the need to be responsible for their own learning and not depend on teachers.

It is good that we allow students to perform their own science investigations and inquiries by providing them with ... the necessary conditions and support they need. (ST 7)

Seeing that it is not the teacher who is coming to do it for him (the student) ... the student sits up and read more. (ST 6)

On the other hand, interviewees who expressed strong beliefs based on traditional conceptions of science teaching believed that allowing students to perform hands-on activities will not produce the desired answers.

... The students' level of education is inappropriate for that (inquiry). If you allow them to do it (inquiry) ... they won't do it as you expect ... (ST 2)

Results from Table 1 shows that the teachers held strong traditional beliefs about "characteristics of science teachers and the learning environment". Most of them agreed that JHS students are more likely to understand science concepts $269(87.4 \%)$ if the teacher is really good at defining and explaining concepts $239(77.6 \%)$ and writing them on the board for students to copy 213(69.2\%). Interviews with a subsample corroborate and provide insight into the teachers' traditional beliefs. Most of the interviewees believed that teachers must create conducive and quiet classroom environments (Table 2) in order to deliver science content to students.

Before the teacher teaches, the environment must be conducive ... you (the teacher) can take them (students) through some poems, riddles, and jumping exercises so that their attention will be in the classroom. (ST 4)

They believe that creating conducive learning environment involves employing traditional strategies such as controlling students' behaviours and managing large class sizes and seating arrangements, through grouping students and telling them what to do and what not to do.

In order to monitor students ... you have to tell them what to do and what not to do ... you have to create sizeable groups that wouldn't be difficult to monitor ... (ST 7) 
4.2 Are there school type (public and private) differences in teachers' beliefs? and, do the differences indicate positive or negative differences in inquiry-based science teaching?

One-way MANOVA results indicate statistically significant school type (public and private) difference in teachers' beliefs about inquiry-based science teaching Wilk's $\lambda=.962, F(4,303)=3.008, p<.05$, partial $\eta^{2}=.038$. Subsequent univariate ANOVAs at Bonferroni adjusted alpha level of .0125 show that there was statistically significant school type difference in teachers' beliefs about "characteristics of science teachers and the learning environment" $F(1,306)$ $=9.199, \mathrm{p}<.0125$, partial $\mathrm{n}^{2}=.029$, with private school teachers $(\mathrm{M}=1.85, \mathrm{SD}=.70)$ holding weaker inquiry-based but stronger traditional beliefs than public school teachers $(\mathrm{M}=2.11, \mathrm{SD}=.79)$ (Table 3$)$.

Table 3. Descriptive Statistics and One-Way MANOVA Results $\left(F\right.$ and $\left.\mathrm{y}^{2}\right)$ for School Type for Components of Beliefs about Inquiry-Based Science Teaching

\begin{tabular}{|c|c|c|c|c|c|c|}
\hline \multirow{2}{*}{ Component of belief } & \multicolumn{2}{|c|}{ Average item mean } & \multicolumn{2}{|c|}{$\begin{array}{l}\text { Average item standard } \\
\text { deviation }\end{array}$} & \multicolumn{2}{|c|}{$\begin{array}{l}\text { School type } \\
\text { difference }\end{array}$} \\
\hline & Public JHSs & Private JHSs & Public JHSs & Private JHSs & $F$ & $y^{2}$ \\
\hline Nature of science curriculum & 4.31 & 4.33 & .56 & .63 & .124 & .000 \\
\hline $\begin{array}{l}\text { Science lesson design and } \\
\text { implementation }\end{array}$ & 4.16 & 4.20 & .58 & .65 & .321 & .001 \\
\hline How students learn science & 4.14 & 4.05 & .57 & .75 & 1.545 & .005 \\
\hline $\begin{array}{l}\text { Characteristics of science teachers } \\
\text { and the learning environment }\end{array}$ & 2.11 & 1.85 & .79 & .70 & $9.199^{*}$ & .029 \\
\hline
\end{tabular}

${ }^{*} p<.0125, \mathrm{~N}=176$ (Public JHS teachers), $\mathrm{N}=132$ (Private JHS teachers)

Note: High means represent inquiry beliefs, low means represent traditional beliefs

In comparison with public school teachers, private school teachers espoused stronger traditional beliefs that a good science teacher is someone who is really good at defining and explaining concepts for students to understand; and writing the concepts on the board for students to copy. Private school teachers also expressed stronger traditional beliefs that science curricula should focus on defining and explaining science concepts and principles students need to know (Table 4).

Table 4. Means and Standard Deviations of Public and Private JHS Teachers' Ratings of Items on Beliefs about "Characteristics of Science Teachers and the Learning Environment"

\begin{tabular}{|c|c|c|c|c|}
\hline \multirow[b]{2}{*}{ Item } & \multicolumn{2}{|c|}{ Mean } & \multicolumn{2}{|c|}{ Standard deviation } \\
\hline & $\begin{array}{l}\text { Public JHS } \\
\text { teachers }\end{array}$ & $\begin{array}{c}\text { Private JHS } \\
\text { teachers }\end{array}$ & $\begin{array}{l}\text { Public JHS } \\
\text { teachers }\end{array}$ & $\begin{array}{c}\text { Private JHS } \\
\text { teachers }\end{array}$ \\
\hline $\begin{array}{l}\text { A good science teacher is someone who is really good at } \\
\text { defining and explaining concepts and principles for JHS } \\
\text { students. }\end{array}$ & 2.16 & 1.80 & 1.11 & .95 \\
\hline $\begin{array}{l}\text { JHS students are more likely to understand a science } \\
\text { concept if the teacher defines and explains it in a way that is } \\
\text { clear and easier to understand. }\end{array}$ & 1.88 & 1.54 & .98 & .81 \\
\hline $\begin{array}{l}\text { The science curriculum should focus on defining and } \\
\text { explaining science concepts and principles that JHS } \\
\text { students need to know. }\end{array}$ & 1.92 & 1.83 & .91 & .95 \\
\hline $\begin{array}{l}\text { Science teachers should write science concepts and } \\
\text { principles on the board for JHS students to copy. }\end{array}$ & 2.47 & 2.21 & 1.22 & 1.09 \\
\hline
\end{tabular}

$\mathrm{N}=176$ (Public JHS teachers), $\mathrm{N}=132$ (Private JHS teachers)

Note: High means represent inquiry beliefs, low means represent traditional beliefs 
Interview responses from a subsample of the teachers corroborate the quantitative results in Table 4. Compared to seven public school teachers, 10 private school teachers expressed beliefs in traditional strategies for creating teacher-centred learning environments. The interviewees believe that teachers should control students' behaviours and deal with large class sizes through strict supervision and making students comply with rules and regulations in classrooms and laboratories.

... If you (the teacher) stand aside and don't exercise strict supervision over the children they will relax ... (ST 4)

Again, the private school interviewees said that students make references from their textbooks during lessons which, distract the students' attention from teachers' content delivery. Therefore, they believe that students should be prevented from making references from textbooks in classrooms in order to create conducive learning environments.

At times pupils ... make references from textbooks in classrooms. When that happens, they do not have full concentration on what the teacher is teaching. So, the teacher ... should tell pupils to close every book except their notebooks or jotters. (ST 11)

4.3 Are there academic qualification (certificate, graduate, and post graduate) differences in teachers' beliefs? and, do the differences indicate positive or negative differences in inquiry-based science teaching?

One-way MANOVA results indicates statistically significant academic qualification difference (certificate, graduate, and post graduate) in teachers' beliefs about inquiry-based science teaching, Wilk's $\lambda=.938, \mathrm{~F}(8,604)=2.470$, $\mathrm{p}<.05$, partial $\mathrm{y}^{2}=.032$. Subsequent univariate ANOVAs at Bonferroni adjusted alpha level of .0125 show that there were statistically significant academic qualification differences in teachers' beliefs about "characteristics of science teachers and the learning environment" $F(2,305)=4.067, \mathrm{p}<.05$, partial $\mathrm{p}^{2}=.026$; and "how students learn science" $\mathrm{F}(2,305)=3.172, \mathrm{p}<.05$, partial $\mathrm{n}^{2}=.020($ Table 5) .

Post hoc analysis show that there was pair wise significant difference between certificate and graduate teachers' beliefs about "characteristics of science teachers and the learning environment", with certificate teachers $(\mathrm{M}=1.91$, $\mathrm{SD}=.71)$ holding weaker inquiry-based but stronger traditional beliefs than graduate teachers $(\mathrm{M}=2.16, \mathrm{SD}=.83)$. However, there were no pair wise significant differences between certificate and post graduate and, graduate and post graduate teachers.

Table 5. Descriptive Statistics and One-Way MANOVA results $\left(F\right.$ and $\left.\eta^{2}\right)$ for Academic Qualification for Components of Beliefs about Inquiry-Based Science Teaching

\begin{tabular}{|c|c|c|c|c|c|c|c|c|}
\hline \multirow{2}{*}{ Component of belief } & \multicolumn{3}{|c|}{ Average item mean } & \multicolumn{3}{|c|}{ Average item standard deviation } & \multicolumn{2}{|c|}{$\begin{array}{l}\text { School type } \\
\text { difference }\end{array}$} \\
\hline & Cert & Grad & $\begin{array}{l}\text { Post } \\
\text { Grad. }\end{array}$ & Cert & Grad & Post Grad & $F$ & $\mathrm{y}^{2}$ \\
\hline $\begin{array}{l}\text { Nature of science } \\
\text { curriculum }\end{array}$ & 4.30 & 4.33 & 4.89 & .60 & .58 & .19 & 1.498 &, 010 \\
\hline $\begin{array}{l}\text { Science lesson design and } \\
\text { implementation }\end{array}$ & 4.13 & 4.24 & 4.67 & .63 & .57 & .58 & 2.121 & .014 \\
\hline How students learn science & 4.04 & 4.21 & 4.56 & .69 & .58 & .51 & $3.172^{* *}$ & .020 \\
\hline $\begin{array}{l}\text { Characteristics of science } \\
\text { teachers and the learning } \\
\text { environment }\end{array}$ & 1.91 & 2.16 & 2.08 & .71 & .83 & 1.04 & $4.067^{* *}$ & .026 \\
\hline
\end{tabular}

Compared to graduate teachers, certificate teachers espoused stronger traditional beliefs that a good science teacher is someone who is really good at defining and clearly explaining concepts for students to understand, and writing the concepts on the board for students to copy. Certificate teachers also espoused stronger beliefs that science curricula should focus on defining and explaining concepts and principles students need to know (Table 6). 
Table 6. Means and Standard Deviations of Certificate, Graduate, and Post Graduate JHS Teachers' Ratings of Items on Beliefs about "Characteristics of Science Teachers and the Learning Environment"

\begin{tabular}{|c|c|c|c|c|c|c|}
\hline \multirow{2}{*}{ Item } & \multicolumn{3}{|c|}{ Average item mean } & \multicolumn{3}{|c|}{ Average item standard deviation } \\
\hline & Cert & Grad & Post Grad & Cert & Grad & Post Grad \\
\hline $\begin{array}{l}\text { A good science teacher is someone } \\
\text { who is really good at defining and } \\
\text { explaining concepts and principles for } \\
\text { JHS students. }\end{array}$ & 1.95 & 2.11 & 2.33 & 1.01 & 1.12 & 1.53 \\
\hline $\begin{array}{l}\text { JHS students are more likely to } \\
\text { understand a science concept if the } \\
\text { teacher defines and explains it in a } \\
\text { way that is clear and easier to } \\
\text { understand. }\end{array}$ & 1.64 & 1.91 & 1.67 & .87 & .99 & 1.16 \\
\hline $\begin{array}{l}\text { The science curriculum should focus } \\
\text { on defining and explaining science } \\
\text { concepts and principles that JHS } \\
\text { students need to know. }\end{array}$ & 1.85 & 1.95 & 1.67 & .89 & 1.01 & .58 \\
\hline $\begin{array}{l}\text { Science teachers should write science } \\
\text { concepts and principles on the board } \\
\text { for JHS students to copy. }\end{array}$ & 2.19 & 2.68 & 2.67 & 1.10 & 1.24 & 1.16 \\
\hline
\end{tabular}

Interviews with subsample corroborate the quantitative results. More certificate teachers espoused traditional beliefs about science learning environment than graduate teachers. Compared to one graduate teacher, five certificate teachers believed that science instructors should create conducive learning environment by controlling students' behaviour. They believed that controlling students' behaviour will make classrooms quiet for teachers to transmit knowledge for students to receive.

The teacher must ensure that ... students are attentive, quiet, looking on the board and following the teacher. (ST 4)

Again, one graduate teacher compared to four certificate teachers expressed traditional beliefs that creating learning environment for hands-on activities should involve putting students into sizeable groups, depending on the class size and availability of science equipment and materials.

If the number (of students) in the classroom is beyond your control ... see to it that they are divided into batches, so that if one batch perform experiment in one day, then the next day will be the turn of another group. (ST 8)

The certificate teachers also believed that putting students into batches and breaking up hands-on activities into sections can make every student participate in the activity and allow students who are misbehaving to be identified and controlled.

When there are a few students in the classroom I can easily control them. If a student is misbehaving, I can see him. (ST 8)

Table 5 shows statistically significant academic qualification difference in JHS teachers' beliefs about "how students learn science". However, post hoc analysis show that there were no pair wise differences between certificate, graduate, and post graduate teachers' beliefs.

\section{Discussion}

Integration of the quantitative and qualitative results indicates that, generally, the teachers held weak beliefs about inquiry-based science teaching but strong beliefs about traditional science teaching, which are negative indicators of 
inquiry-based science teaching. Specifically, the teachers held weak inquiry-based beliefs about "characteristics of science teachers and the learning environment", "how students learn science", "nature of science curriculum", and "science lesson design and implementation". Instead, the teachers held strong traditional beliefs about "characteristics of science teachers and the learning environment", "how students learn science", "nature of science curriculum", and "science lesson design and implementation". This finding differs from many findings (Herranen, Kousa, Fooladi, \& Aksela, 2019; Holland, 2018; Min et al., 2020; Tang et al., 2020) in places, like USA, where there are significant successes in the implementation of inquiry-based science curricula. The current finding suggests that most teachers in the research setting, like teachers in similar settings, hold beliefs that are directly contrary to important goals and elements of innovative (inquiry-based) science curricula. In such places, teachers' existing traditional belief structures may influence them to alter implementation of innovative curricula in contradiction to the underlying philosophy and goals of the intended curricula (Bryan, 2012). When teachers in such places encounter challenges in their attempts to implement innovative science curricula, they either ignore aspects of the reform initiatives that are inconsistent with their beliefs or translate elements of the curricula to align with their beliefs.

In places where there are serious challenges in the implementation of innovative (inquiry-based) science curricula, most of the teachers believe that only the exceptionally gifted teacher is capable of employing innovative strategies and creativity in the classroom. Most of the teachers believe that the average teacher is incapable of employing innovative strategies and creativity in the classroom (Schommer, 1990).

The aforementioned finding from this research is contrary to the findings of Ramnarain (2016) and Ramnarain and Hlatswayo (2018). These researchers found that teachers in their studies held positive beliefs about inquiry-based science teaching but, the teachers were unable to implement inquiry-based (innovative) science instruction because of lack of resources, time constraints, large class sizes, and other external contextual factors. Similarly, Ogegbo (2021), Maseko and Khoza (2021) and, Mkimbili, Tiplic, and Odegaard (2017) found that external contextual factors are significant constraints for teachers implementing inquiry-based (innovative) science instruction in classrooms. External contextual factors are major indicators of instructional behaviours in places, like Africa, where are serious challenges in the implementation of innovative (inquiry-based) science curricula. However, the finding from this study suggests that teachers' beliefs is an important psychological (internal) indicator of instructional behaviour in places where there are serious challenges in the implementation of innovative (inquiry-based) science curricula. After all, if teachers are given sufficient resources, adequate time, small class sizes, and other favourable external conditions but, if the teachers do not hold strong beliefs about and informed conceptions of inquiry (Mohammed \& Amponsah, 2021), it will still be difficult for them to implement inquiry-based (innovative) science curricula initiatives.

Again, finding from this research indicates that most of the teachers held strong beliefs about "how students learn science", "nature of science curriculum", and "science lesson design and implementation" based on either traditional conceptions of science teaching or partial conceptions of inquiry. This finding confirms researchers assertion that teachers can hold beliefs about science teaching based on incorrect or incomplete knowledge (Bryan, 2012; Pajares, 1992). Many teachers equate hands-on science activities with inquiry-based instruction but, not all hands-on science activities are inquiry-based. Traditional science teaching and learning and confirmatory laboratory experiences that the teachers had when they were students in elementary and high schools largely influenced their formation of strong beliefs about hands-on science instruction. When beliefs about science teaching formed on incorrect or incomplete knowledge are used continuously over time, they become robust and resistant to change even when they are confronted with correct scientific explanations (Pajares, 1992). This finding and others (Mohammed \& Amponsah, 2021) suggest that most teachers in the current research setting, like teachers in similar settings, have developed deep convictions that traditional hands-on science activities are inquiry-based (innovative) instructional practices. These deep convictions strongly influence how the teachers conceptualize and organize innovative science instructional tasks and, strongly influence their practices in classrooms (Bryan, 2012).

These strongly held beliefs about traditional hands-on science instruction can only change when specific inquiry-based (innovative) professional developments, interventions, and methods courses are designed to deliberately persuade the teachers to understand that their existing beliefs and conceptions are inconsistent with the philosophy and goals of innovative science curricula initiatives (Pajares, 1992). Sustained engagement of teachers in specifically designed professional developments and methods courses are effective in changing their teacher-centered beliefs and practices toward student-centered beliefs and practices (Buldur, 2017; Herranen et al., 2019; Holland, 2018; Min et al., 2020; Tatar, 2015; Veal et al., 2016).

Results from this research show that there was significant school type difference in teachers' beliefs about science 
teaching. Specifically, there was significant school type difference in teachers' beliefs about "characteristics of science teachers and the learning environment", with private school teachers holding weaker inquiry-based but stronger traditional beliefs than public school teachers. This suggests that private school teachers' beliefs are more negative indicators of inquiry-based science teaching than public school teachers' beliefs. Previous studies indicate that time constraints, loaded curriculum, teacher collaboration, economic and educational status of a place, school culture, student support, laboratory facilities, class size, prescribed curriculum, loaded curriculum, teaching experience, gender, students' safety, nature of examinations, teacher accountability, students' confidence and interest, technology and resources, subject-matter specialization, availability of laboratories, administrative support, financial support, and language of instruction are external contextual factors that significantly influence teachers' beliefs and implementation of innovative (inquiry-based) science curricula (Baroudi \& Rodjan Helder, 2021; Correia \& Harrison, 2020; Isiksal-Bostan et al., 2015; Karaman \& Karaman, 2013; Kind, 2016; Maseko \& Khoza, 2021; Mkimbili et al., 2017; Ogegbo, 2021; Ramnarain, 2016; Ramnarain \& Hlatswayo, 2018; Tahmina Hoq, 2019; Tang et al., 2020). However, this study is among the few studies that show that school type is a contextual factor that significantly influences teachers' beliefs about inquiry-based (innovative) science teaching.

The difference in beliefs about science teaching between public and private school teachers is largely because of the heavy reliance of private schools on traditional teaching, learning, and assessment practices. Due to the desire of private schools in this study context, like private schools in similar contexts, to obtain high pass rates in external examinations, they engage in more traditional teaching, learning, and assessment practices than the public schools. These contextual practices might have resulted in the private school teachers developing stronger traditional but weaker inquiry-based beliefs than the public school teachers.

Again, results from this research show that there was significant academic qualification difference in teachers' beliefs about science teaching. Specifically, there was significant academic qualification difference in teachers' beliefs about "characteristics of science teachers and the learning environment", with certificate teachers holding weaker inquiry-based but stronger traditional beliefs than graduate teachers. This suggests that certificate teachers' beliefs are more negative indicators of inquiry-based science teaching than graduate teachers' beliefs. This finding is similar to that of Macugay and Bernardo (2013) but contradicts the finding of Kind (2016).

Individuals' beliefs about science teaching are formed from their experiences as students learning science, observations of science teaching and learning experiences, participation in science education courses, participation in science teaching internships and, professional teaching practices (Bryan, 2012). Again, individuals' experiences in methods courses and their encounters with methods course tutors during preservice teacher education are influential in reinforcing their beliefs about science teaching (Lasley, 1980). The differences in beliefs between certificate and graduate teachers in this study could partly be due to differences in science teaching and learning experiences they had. Compared to the graduate teachers, the certificate teachers have taken less number of science courses, have less exposure to science teaching experiences, have less encounter with science teaching techniques, and have less images of science instructional activities.

Again, while most of the graduate teachers $64(61.0 \%)$ in this study had preservice teacher education and had taken science methods courses, more than half of the certificate teachers 102(51.0\%) were SSCE and WASSCE holders who have never taken any methods course at all. Due to their lack of or limited exposure to teaching and learning theories taught in methods courses, the certificate teachers lack or have limited appreciation of students' involvement in science instruction. These experiences might have resulted in the certificate teachers forming weaker inquiry-based but stronger traditional beliefs about science teaching.

\section{Conclusions}

One finding suggests that most teachers in the current research setting, like teachers in similar settings, hold weak beliefs about inquiry teaching that are negative indicators of innovative (inquiry-based) science teaching. Another finding suggests that most teachers in the research setting hold strong beliefs about inquiry teaching based on either traditional conceptions of teaching or partial conceptions of inquiry. As a result, the teachers have developed strong convictions that traditional hands-on science activities are inquiry-based instructional practices. Again, findings from the study show significant school type and academic qualification differences in teachers' beliefs about science teaching, with private school and certificate teachers holding weaker inquiry-based but stronger traditional beliefs than public school and graduate teachers respectively. These suggest that private school and certificate teachers' beliefs are more negative indicators of inquiry-based science teaching than public school and graduate teachers' beliefs respectively. 
One implication of the findings is that currently most teachers in the research setting do not hold strong beliefs necessary for the implementation of innovative (inquiry-based) science curricula. Other implications of the findings are that currently there are likely to be significant differences in any implementation of innovative science curricula between public and private school teachers and, certificate and graduate teachers.

Based on the findings it is recommended that science teachers in the research setting, like teachers in similar settings, should be engaged in sustained inquiry-based (innovative) professional develops, interventions, and methods courses designed to deliberately promote their beliefs about inquiry. It is also recommended that inquiry-based professional developments and methods courses should be designed based on teachers' school type and academic qualifications.

Further studies are necessary to examine the outcome of professional developments on teachers' beliefs in this study context. Again, further studies are necessary to examine the interactions of teachers' beliefs and external factors on inquiry-based science instruction in this context.

\section{Limitations}

This study has a number of limitations. First, the sample was drawn from a population of junior high school (JHS) teachers in Ghana. Therefore, caution must be exercised in generalizing findings from this study outside this population. Again, four components of beliefs about inquiry-based science teaching were examined. Care must be taken in generalizing findings from this study beyond these four components.

\section{References}

Ajzen, I. (2001). Nature and operation of attitudes. Annual Reveiw of Psychology, 52, 27-58. https://doi.org/10.1146/annurev.psych.52.1.27

Anderson, R. D. (2002). Reforming science teaching: What research says about inquiry. Journal of Science Teacher Education, 13(1), 1-12. https://doi.org/10.1023/A:1015171124982

Baroudi, S., \& Rodjan Helder, M. (2021). Behind the scenes: teachers' perspectives on factors affecting the implementation of inquiry-based science instruction. Research in Science and Technological Education, 39(1), 68-89. https://doi.org/10.1080/02635143.2019.1651259

Bryan, L. A. (2012). Research on science teacher beliefs. In J. Fraser, Barry J., Tobin, Kenneth, McRobbie, Campbell (Ed.), Second International Handbook of Science Education (1st ed., pp. 477-495). Springer, Dordrecht. https://doi.org/10.1007/978-1-4020-9041-7

Buldur, S. (2017). A longitudinal investigation of the preservice science teachers' beliefs about science teaching during a science teacher training programme. International Journal of Science Education, 39(1), 1-19. https://doi.org/10.1080/09500693.2016.1262084

Bunting, C. E. (1984). Dimensionality of teacher education beliefs: An exploratory study. Journal of Experimental Education, 52(4), 195-198. https://doi.org/10.1080/00220973.1984.11011893

Chabalengula, V. M., \& Mumba, F. (2012). Inquiry-based science education : A scenario on Zambia' s high school science curriculum. Science Education International, 23(4), 307-327.

Correia, C. F., \& Harrison, C. (2020). Teachers' beliefs about inquiry-based learning and its impact on formative assessment practice. Research in Science and Technological Education, 38(3), 355-376. https://doi.org/10.1080/02635143.2019.1634040

Crawford, B. A. (2007). Learning to teach science as inquiry in the rough and tumble of practice. Journal of Research in Science Teaching, 44(4), 613-642. https://doi.org/10.1002/tea.20157

Creswell, J. W. (2009). Research Design: Qualitative, Quantitative, and Mixed methods approaches (4th ed.). Thousand Oaks, California: SAGE Publications, Inc.

Creswell, J. W., \& Plano Clark, V. L. (2007). Designing and conducting mixed methods research (1st ed.). Thousand Oaks, California: SAGE Publications Inc. Retrieved from http://scholar.google.com/scholar?hl=en\&btnG=Search\&q=intitle:Choosing+a+mixed+methods+design\#

Curriculum Research and Development Division. (2012). National syllabus for integrated science: Junior high school. Accra, Ghana: Curriculum Research and Development Division. 
Eisenhart, M. A., Shrum, J. L., Harding, J. R., \& Cuthbert, A. M. (1988). Teacher Beliefs: Definitions, Findings, and Directions. Educational Policy, 2(1), 51-70. https://doi.org/10.1177/0895904888002001004

Furtak, E. M., Seidel, T., Iverson, H., \& Briggs, D. C. (2012). Experimental and Quasi-Experimental Studies of Inquiry-Based Science Teaching: A Meta-Analysis. Review of Educational Research, 82(3), 300-329. https://doi.org/10.3102/0034654312457206

Herranen, J., Kousa, P., Fooladi, E., \& Aksela, M. (2019). Inquiry as a context-based practice-a case study of pre-service teachers' beliefs and implementation of inquiry in context-based science teaching. International Journal of Science Education, 41(14), 1977-1998. https://doi.org/10.1080/09500693.2019.1655679

Holland, B. T. (2018). Research and Teaching: Impact of a Departmental Instructional Skills Course on Graduate Students' Beliefs About Science Teaching and Learning. Journal of College Science Teaching, 047(06), 57-65. https://doi.org/10.2505/4/jcst18_047_06_57

Isiksal-Bostan, M., Sahin, E., \& Ertepinar, H. (2015). Teacher beliefs toward using alternative teaching approaches in science and mathematics classes related to experience in teaching. International Journal of Environmental and Science Education, 10(5), 603-621. https://doi.org/10.12973/ijese.2015.257a

Jacob, S. A., \& Furgerson, S. P. (2012). The qualitative report writing interview protocols and conducting interviews: Tips for students new to the field of qualitative research. The Qualitative Report, 17(42), 1-10.

Karaman, A., \& Karaman, P. (2013). Examining the Beliefs of Prospective Elementary and Science Teachers Regarding Reformed Science. International Journal of Research in Teacher Education, 4(3), 1-9.

Kazempour, M. (2014). The Interrelationship of Science Experiences, Beliefs, Attitudes, and Self-Efficacy: A Case Study of a Pre-Service Teacher with Positive Science Attitude and High Science Teaching Self-Efficacy. Journal of Education and Learning (EduLearn), 8(1), 51. https://doi.org/10.11591/edulearn.v8i1.205

Kind, V. (2016). Preservice Science Teachers' Science Teaching Orientations and Beliefs About Science. Science Education, 100(1), 122-152. https://doi.org/10.1002/sce.21194

Lasley, T. J. (1980). Preservice Teacher Beliefs about Teaching. Journal of Teacher Education, 31(4), 38-41. https://doi.org/10.1177/002248718003100410

Macugay, E. B., \& Bernardo, A. B. I. (2013). Science coursework and pedagogical beliefs of science teachers : The case of science teachers in the Philippines. Science Education International, 24(1), 63-77.

Mansour, N. (2013). Consistencies and Inconsistencies Between Science Teachers' Beliefs and Practices. International Journal of Science Education, 35(7), 1230-1275. https://doi.org/10.1080/09500693.2012.743196

Marec, C. É., Tessier, C., Langlois, S., \& Potvin, P. (2021). Change in Elementary School Teacher's Attitude Toward Teaching Science Following a Pairing Program. Journal of Science Teacher Education, 00(00), 1-18. https://doi.org/10.1080/1046560X.2020.1856540

Maseko, B., \& Khoza, H. C. (2021). Exploring the Influence of Science Teaching Orientations on Teacher Professional Knowledge Domains: A Case of Five Malawian Teachers. Eurasia Journal of Mathematics, Science and Technology Education, 17(12), em2041. https://doi.org/10.29333/ejmste/11333

Min, M., Akerson, V., \& Aydeniz, F. (2020). Exploring Preservice Teachers' Beliefs about Effective Science Teaching through Their Collaborative Oral Reflections. Journal of Science Teacher Education, 31(3), $245-263$. https://doi.org/10.1080/1046560X.2019.1690818

Mkimbili, S. T., Tiplic, D., \& Ødegaard, M. (2017). The role played by contextual challenges in practising inquiry-based science teaching in Tanzania secondary schools. African Journal of Research in Mathematics, Science and Technology Education, 21(2), 211-221. https://doi.org/10.1080/18117295.2017.1333752

Mohammed, S. M., \& Amponsah, K. D. (2021). Teachers' and educational administrators' conceptions of inquiry: Do they promote or constrain inquiry-based science teaching in junior high schools? Journal of Curriculum and Teaching, 10(3), 58-71. https://doi.org/10.5430/jct.v10n3p58

Mohammed, S. M., Amponsah, K. D., Ampadu, E., \& Kumassah, E. K. (2020). Extent of Implementation of Inquiry-based Science Teaching and Learning in Ghanaian Junior High Schools. Eurasia Journal of Mathematics, Science and Technology Education, 16(12), 1-15. https://doi.org/10.29333/ejmste/9373

Mugabo, R. L. (2012). Introduction of Inquiry-based Science Teaching in Rwandan Lower Secondary Schools: Teachers ' attitudes and perceptions. University of KwaZulu-Natal. 
National Research Council. (2012). A framework for K-12 science education: Practices, crosscutting concepts, and core ideas. Washington D.C.: National Academcy Press.

Nespor, J. (1987). The role of beliefs in the practice of teaching. Journal of Curriculum Studies, 19(4), 317-328. https://doi.org/10.1080/0022027870190403

Ogegbo, A. A. (2021). Relationships between High School Teachers' Understanding and their Reported Practices of Inquiry-based Pedagogy in Science Classrooms in Nigeria. African Journal of Research in Mathematics, Science and Technology Education, O(0), 1-12. https://doi.org/10.1080/18117295.2021.1965790

Ornstein, A. (2006). The Frequency of Hands-On Experimentation and Student Attitudes toward Science: A Statistically Significant Relation. Journal of Science Education and Technology, 15(3/4), 285-297.

Pajares, M. F. (1992). Teachers' Beliefs and Educational Research: Cleaning Up a Messy Construct. Review of Educational Research, 62(3), 307-332. https://doi.org/10.3102/00346543062003307

Ramnarain, U. (2016). Understanding the influence of intrinsic and extrinsic factors on inquiry-based science education at township schools in South Africa. Journal of Research in Science Teaching, 53(4), 598-619. https://doi.org/10.1002/tea.21315

Ramnarain, U., \& Hlatswayo, M. (2018). Teacher beliefs and attitudes about inquiry-based learning in a rural school district in South Africa. South African Journal of Education, 38(1), 1-10. https://doi.org/10.15700/saje.v38n1a1431

Saad, R., \& BouJaoude, S. (2012). The relationship between teachers' knowledge and beliefs about science and inquiry and their classroom practices. Eurasia Journal of Mathematics, Science and Technology Education, 8(2), 113-128. https://doi.org/10.12973/eurasia.2012.825a

Sampson, V., Enderle, P., \& Grooms, J. (2013). Development and Initial Validation of the Beliefs About Reformed Science Teaching and Learning (BARSTL) Questionnaire. School Science and Mathematics, 113(1), 3-15. https://doi.org/10.1111/j.1949-8594.2013.00175.x

Schommer, M. (1990). Effects of Beliefs About the Nature of Knowledge on Comprehension. Journal of Educational Psychology, 82(3), 498-504. https://doi.org/10.1037/0022-0663.82.3.498

Silm, G., Tiitsaar, K., Pedaste, M., Zacharia, Z., \& Papaevripidou, M. (2017). Teachers' Readiness to Use Inquiry-Based Learning: An Investigation of Teachers' Sense of Efficacy and Attitudes toward Inquiry-Based Learning. Science Education International, 28(4), 315-325.

Ssempala, F. (2017). Science Teachers understsanding and practice of inquiry-based instruction in Uganda. (Syracuse University). Syracuse University. $\quad$ Retrieved from http://surface.syr.edu/etd\%0Ahttp://surface.syr.edu/etd/690

Tahmina Hoq. (2019). Probing Beliefs of Secondary Science Teacher on Inquiry-Based Teaching in Bangladesh. US-China Education Review A, 9(4), 171-181. https://doi.org/10.17265/2161-623x/2019.04.002

Tang, H., Qiu, C., Meng, L., Li, Y., \& Zhang, J. (2020). Factors Predicting Inquiry-Based Teaching in Science Across One Belt One Road Countries and Regions: A Multilevel Analysis. SAGE Open, 10(2). https://doi.org/10.1177/2158244020932511

Tatar, N. (2015). Pre-Service Teachers ' Beliefs About the Image of a Science Teacher and science teaching. Journal of Baltic Science Education, 14(1), 34-44.

Tondeur, J., van Braak, J., Ertmer, P. A., \& Ottenbreit-Leftwich, A. (2016). Understanding the relationship between teachers' pedagogical beliefs and technology use in education: a systematic review of qualitative evidence. Educational Technology Research and Development 2016 65:3, 65(3), 555-575. https://doi.org/10.1007/S11423-016-9481-2

Veal, W. R., Riley Lloyd, M. E., Howell, M. R., \& Peters, J. (2016). Normative beliefs, discursive claims, and implementation of reform-based science standards. Journal of Research in Science Teaching, 53(9), 1419-1443. https://doi.org/10.1002/tea.21265

Wolf, S. J., \& Fraser, B. J. (2008). Learning environment, attitudes and achievement among middle-school science students using Inquiry-based laboratory activities. Research in Science Education, 38(3), 321-341. https://doi.org/10.1007/s11165-007-9052-y 


\section{Copyrights}

Copyright for this article is retained by the author(s), with first publication rights granted to the journal.

This is an open-access article distributed under the terms and conditions of the Creative Commons Attribution license (http://creativecommons.org/licenses/by/4.0/). 